\title{
'Grandmas' in debate: A first-person story told in Taiwan's presidential debate as a rhetorical device and public reactions to its credibility
}

\author{
Ping-Hsuan Wang*
}

\begin{abstract}
This study examines data from a 2016 presidential debate in Taiwan to explore the use of first-person narrative in political discourse as a rhetorical device, and how public reactions to its credibility are influenced by the narrative's context. While previous studies of political debate discourse (e.g. Kuo 2001) investigate, for example, the use of "constructed dialogue" (Tannen 2007), there is a lack of studies focusing on first-person narrative in political debates. Using three-level positioning as outlined by Bamberg (1997), I analyze a narrative featuring a grandma character told by presidential candidate Eric Chu, also comparing it to another candidate James Soong's "grandma narrative." I argue that the context places constraints on the effects of their narratives. Whereas Chu's narrative, a traditional Labovian firstperson story, is widely ridiculed with memes for its lack of credibility, Soong's narrative, a habitual narrative, receives little attention.

The analysis shows how Chu's narrative serves his rhetorical purposes and suggests why the public doubts its credibility. At level 1 (characters positioned vis-à-vis one another), Chu presents himself as non-agentive with constructed dialogue, thereby excusing an earlier decision he made -- failing to keep his promise to finish his term as a mayor. At level 2 (speaker positioned to audience), he switches from Mandarin to Taiwanese, a local dialect, which can be seen as an appeal to his current audience. At level 3 (identity claims locally instantiated), the grandma character draws on the archetype of elderly women in Taiwanese culture, fundamental to national economic growth, while his description of praying at a temple casts him against the local tradition of religious practices in Taiwan. The study helps fill the knowledge gap regarding first-person narrative in political discourse, while highlighting the context in which political narratives are embedded and contributing to understanding positioning in Taiwanese public discourse.
\end{abstract}

Keywords. narrative analysis, three levels of positioning, political discourse, presidential debate, Taiwan, credibility

1. Introduction. Narrative is a powerful linguistic device that communicates meaning and it serves a multitude of functions in human interaction ranging from identity construction (e.g., Schiffrin 1996) to argumentation (e.g., Carranza 1999). It is, therefore, not uncommon to see narratives in political speech, even in political debates, where each politician's time to speak is strictly allotted. Few studies on political discourse, however, have closely examined narratives in

\footnotetext{
* An earlier version of this paper was presented at the Linguistic Society of America Annual Meeting 2017, January 5-8, 2017, Austin, Texas. I am grateful to Cynthia Gordon for her helpful comments on my abstract. I thank Anna De Fina for her course instructions in Discourse Analysis: Narrative. I thank Cynthia Gordon, Heidi Hamilton, Deborah Tannen, and colleagues in the Georgetown Interaction Lab for their valuable feedback on the analysis of my data and the direction of my presentation. I also thank the two anonymous reviewers for their comments. Author: Ping-Hsuan Wang (pw433@georgetown.edu), Georgetown University.
} 
political debates. Past research on political discourse has, for the most part, taken a critical perspective, or Critical Discourse Analysis (CDA), that focuses on issues such as ideology, power relations, and dominance (e.g., Yang 2013). Scholars have also taken various approaches to political discourse, including politicians' uses of direct quotation (e.g., Kuo 2001) and pronouns (e.g., Kuo 2002), and how they talk about their families (e.g., Sclafani 2015). The present paper adds to the works on political discourse that adopt narrative analysis (e.g., Duranti 2006, Shenhav 2005a) by investigating the use of narratives in the first of the two 2016 presidential debates in Taiwan and how aspects of the context influenced public perception of the two narratives. I argue that narrative is a discourse strategy employed by the candidates in an attempt to enhance what Tannen (2007) calls "conversational involvement" with the public viewers, to increase the credibility of their claims, and to justify their positions during political campaigns. Also, I underscore how the context in which narratives are situated can undermine their effects. To substantiate, I borrow the theoretical construct of three levels of positioning proposed by Bamberg (1997) to delineate how the two presidential candidates present themselves as relatable and, at the same time, establish what Duranti (2006) terms "existential coherence." Specifically, I examine positioning in the context of the narrative's structural parts (as outlined by Labov and Waletzky 1967) and by drawing on Tannen's (2007) theorizing on involvement in discourse. While Labovian structural elements and involvement features are present, the narrative is not viewed as persuasive or credible, and my positioning analysis demonstrates how and suggests why this might be.

Two of the three 2016 presidential candidates in Taiwan, Eric Chu and James Soong, incorporated narratives into their speeches during the first debate on December 27, 2015; while both narratives featured a grandma character, only one of them later became the subject of numerous parodies. The two grandmas are both the center of the narratives, but public perceptions vary to a great extent due primarily to the contexts in which the narratives are situated. Although narrative, as a discourse strategy, is supposedly a powerful rhetorical device employed to increase authenticity, in Chu's case, not only did it not work to his advantage in vindicating his action of running for presidency but his narrative was publicly mocked. This paper addresses this issue by focusing on the context where the two narratives are embedded, including the immediate context of the debate and the larger social context in Taiwan. In exploring positioning and its relationship to situational and sociocultural context, this study contributes to the research of narrative analysis in political debates. It also highlights linguistic strategies that help accomplish positioning in narrative, among them constructed dialogue, repetition, and code-switching. In what follows, I first review previous studies of discourse analysis in political speech and suggest how narrative analysis can add to the existing literature. Then I provide some background for the data before presenting my analysis of the two candidates' positioning at different levels in their narratives. Finally, I conclude with the implications and significance of bringing narrative analysis into research of political discourse.

\section{Literature review}

\subsection{POLITICAL DISCOURSE ANALYSIS}

In defining political discourse, van Dijk (1997) outlines some ways of delimiting the object of study. First and foremost, many studies identify political discourse by its political actors or authors, that is, politicians. Hodges' (2011) work, for example, analyzes presidential speeches by George W. Bush in the aftermath of 911 to illustrate how the Bush administration creates a "grand narrative" (a dominant discourse about certain social issues through which they are 
framed and interpreted) of war on terror propagated as America's response to terrorism. Second, viewing politics as a series of communicative events, van Dijk consider the recipients such as the public to be a focus of political discourse analysis. Third, political discourse analysis studies text and talk in certain activities and practices. Political practices carry political functions and implications, such as legislating, debating, and protesting. In this sense, social movements are included as part of the political discourse. Last but not least, van Dijk sees context as a deciding element for defining what sort of discourse is political in that "politicians talk politically also (or only) if they and their talk are contextualized in such communicative events such as cabinet meetings, parliamentary sessions, election campaigns," and so on (p. 14). In this paper, I identify these four fundamental criteria for my data to be considered political discourse; I emphasize especially the context of these narratives in that they are told by the presidential candidates to accomplish certain political aims.

\subsection{APPROACHES TO POLITICAL DISCOURSE}

Research on political discourse comes largely from the framework of Critical Discourse Analysis (CDA). CDA primarily deals with social problems, which include political issues, such as dominance, discrimination, and inequality (e.g., Miller \& Fox 1995, Gamson 1992). Theorists whose studies follow the main principles of CDA maintain that power relations are discursive, that is, social problems like power abuse are represented in discourse (see Fairclough \& Wodak 1997). Critical discourse analysts aim to explain, for example, "social inequality as it is expressed, signalled, constituted, legitimized and so on by language use (or in discourse)" (Wodak 2001:2). Within CDA, political discourse is also described as "fundamentally argumentative" and it "primarily involves practice argumentation" (Fairclough and Fairclough, 2012:1). Studies adopting a CDA model include Yang's (2013) analysis of Taiwan's 2010 national debate on Economic Cooperation Framework Agreement (ECFA). Building on Oddo's (2011) study on discourse representation of "Us versus Them" in U.S. presidential addresses, Yang examines how then-President Ying-jeou Ma creates dominance over his opponent, thenChairperson Ing-wen Tsai (DPP), by positively evaluating Us while negatively describing Them in the discourse of the debate.

In addition to CDA, scholars have drawn on multiple other approaches to investigate various aspects of political discourse. Sclafani (2015), for example, borrows the concept of framing, or a definition of the situation (Goffman 1974), and demonstrates how Republican candidates in a U.S. presidential primary present their family identities at home (e.g., as husband or father) and use these family references to frame their political identities by blending together the audience's understanding of the family and the state, family safety and national security. Kuo (2001) investigates videotaped data from two Taipei mayoral debates in 1998, examining the debaters' use of reported speech. She builds on Tannen's ([1989] 2007) idea that reported speech is in fact "constructed dialogue," in which speakers situate words in a new context and therefore create new meanings. Kuo, in this vein, argues that the debaters incorporate direct quotations in their speeches to create involvement with the audience in the sense making process, dramatize key elements in narrative for rhetorical purposes, and bring in the voice of authoritative and nonpartisan figures for self-promotion. Kuo (2002) analyzes the same data set to illuminate the discourse functions of the second-person singular pronoun $n \check{~}$ in Mandarin Chinese. She identifies a change of how the debaters use $n \check{l}$, from referring to the audience/voters to create solidarity in the first debate to addressing the opponents to express antagonism in the second debate, therefore suggesting a shift of interactive goal between the two debates. 


\subsection{NARRATIVE ANALYSIS IN POLITICAL DISCOURSE}

Discussing narrative's relevance to political theory, Bottici (2010) puts that "narratives are ways to connect events in a nonrandom way, and therefore they are a powerful means to provided meaning to the political world we live in" (p. 920). In this sense, narrative serves as a way in which we observe the process of world making and sense making in politics and the construction of our political identities. As she notes, scholarly attention to narrative in the study of politics and political theory is rather recent (e.g., Duranti 2006, Shenhav 2005a, Schubert 2010, Souto-Manning 2014). Shenhav (2005a) proposes a new framework for defining narrative in political discourse analysis by following the structuralist tradition, that is, the scholarship that sees narrative as consisting of structural units (e.g., Labov \& Waletzky 1976) and diverging from other approaches such as narrative dimensions, or the extent to which a narrative is "tellable," "embedded," "linear," and so on (e.g., Ochs \& Capps 2001). He suggests two levels on which narrative analysis operates: the "thin" level analysis that looks into the components of narrative such as the organization of events and the "thick" level analysis that include contextual viewpoints relating to the storytelling process (p. 87). Extending Linde's (1993) concept of creating coherence in life stories, Duranti (2006) argues that politicians have the awareness that their emotional stance is articulated through talk and aim to project a coherent image of themselves, or what he terms "existential coherence," as people "whose past, present, and future actions, beliefs, and evaluations follow some clear basic principles, none of which contradicts another" (p. 469). In his study, he investigates former Representative Walter Capps' construction of "political self" in his campaign from 1995 to 1996. Given my interest in how the candidates in 2016 Taiwan's presidential election present themselves in the debate, I focus on the narratives they told, and use positioning theory to do so.

\subsection{THREE LEVELS OF POSITIONING}

Positioning theorists hold that an individual's identity is constructed through discursive practices in social interaction. Davies and Harré (1990) define positioning as "the discursive process whereby selves are located in conversations as observably and subjectively coherent participants in jointly produced storylines" (p. 37). This take on self-presentation highlights not only the relationships between the speaker and the talk but also the relationships between speaker and audience. Bamberg (1997) elaborates the concept of positioning and puts forward a threelevel model of positioning in narrative, mapping out the dimensions of self-presentation in storytelling activity. Level 1 pertains to how the story characters are positioned in relation to one another; level 2 stresses the interaction in the storytelling world, that is, how the storyteller positions himself or herself to the audience; level 3 addresses self and identity or how the narrators "position themselves to themselves" (p. 337). De Fina (2013) illustrates that Bamberg's three-level positioning bridges interactions on a micro level and dominant discourses on a macro level. Analyzing a narrative about an ethnic conflict that reveals language ideology in the life of an immigrant, she demonstrates that level 3 positioning "allows for an analysis of connections between local identity claims and negotiations and macro-level social processes" (p. 47).

\section{Data and method}

I analyze narratives drawn from the first of two Taiwan's presidential debates leading up to the January 16, 2016 election. The debate was 155 minutes in length, and was televised and live 
streamed on YouTube by Taiwan Public Television. The debate was in the format of four stages: opening statements, questions by journalists, cross-examination, and closing statements. Three presidential candidates, Eric Chu (Li-luan Chu), James Soong (Chu-yu Soong), and Ing-wen Tsai participated in the debate, each representing a political party. Tsai, the chairperson of Democratic Progressive Party (DPP) won the election. The present analysis is based on the narratives told by Chu and Soong; Chu's was told during cross-examination while Soong's was part of his own closing statement. Segments of their speeches were transcribed in Mandarin Chinese, and then translated into English for analysis. Chu's first-person narrative is the focus of my analysis; Soong's habitual narrative is used as a point of contrast and comparison.

Before Chu announced his decision to run for presidency, he had been the chairperson of Kuomintang (KMT) and, at the same time, the mayor of New Taipei City since 2014, while another candidate, Hsiu-chu Hung, was the candidate officially nominated by the party on June 14, 2015. Three months later, at KMT's congress convention on October 17, 2015, Hung's candidacy was revoked by delegates' voting and Chu was selected to replace Hung as the presidential candidate. Chu's decision to run not only contradicted his frequent promise in the interviews in mass media, 24 times at different occasions in total, that he would commit to serving his second term as mayor, that he would “do the job well, and serve the full term" (做好 做滿, zuò hăo zuò măn), but also added to his record of leaving one position for another, including resigning as a legislator to run for Taoyuan County Magistrate election in 2001, and resigning from the second term of magistracy after being appointed Vice Premier in 2009. The replacement of Hung with Chu also was controversial.

Soong, the chairperson of People First Party (PFP) has a long history of political engagement in Taiwan, including running for presidency. In 1994, Soong, a long-time member of KMT, was elected as the Governor of Taiwan Province, a position that was later eliminated in 1998 following the decision made by the National Development Council to resolve a contradiction in administrative territory. After losing the KMT presidential nomination, he decided to run independently in the 2000 presidential election. After losing the election by a close margin to DPP candidate Shui-bian Chen, Soong left KMT and founded PFP, and in 2004, partnered with the KMT candidate Chan Lien to run in the presidential election. In 2006, he ran for Taipei City mayoral election, garnering only $4 \%$ of the cast ballots. In 2012, he registered for the candidacy for presidency and was defeated by the KMT candidate Ying-jeou Ma. In 2016, he again ran in the presidential election as a PFP candidate and finished third of all three candidates.

Standing out in both Chu's and Soong's narratives are the grandma characters, which provides a unique opportunity for comparison, especially given the different reactions to the stories. In Taiwanese, a Chinese language widely spoken in Taiwan, "Ama" not only means one's grandma but can be used to refer to any old lady as an intimate term. It denotes a tender, caring, and family-oriented personality, a female figure in the household and, at the same time, an economically substantial role because, in the late 90s after World War II, women of that generation contributed to the economic growth in Taiwan by being in the manufacturing industry and other labor intensive workplaces. Nowadays, their image is also tied to traditions and authenticity, which is often used as a marketing strategy in advertising. We can say that the candidates alluded to some of these characteristics of Ama in their narratives.

\section{Analysis}

\subsection{CHU'S NARRATIVE}


Eric $\mathrm{Chu}$, the KMT candidate, provided the following narrative in the second round of cross-examination when his publicly criticized motive and action of leaving his current position as the mayor of New Taipei City to run in the presidential election was questioned by the DPP candidate Ing-wen Tsai. The confrontation at this stage characterizes the debate as one of the "essential instances of persuasive attack and defense" (Benoit \& Wells 1996). The narrative was told by Chu with a clear political aim in a political context: to answer his opponent's question, deny the accusation, and reestablish his credibility. However, the narrative was not perceived as credible by audiences (as later mocking of it showed); in what follows I identify how examining the three levels of positioning in Chu's narrative illustrates the rhetorical nature of this firstperson narrative in the debate and Chu's attempt to counter the accusation he faced and to justify his decision of joining the presidential election. However, because of the argumentative nature in the immediate context of the debate and the public scrutiny to which Chu's reputation was subject to in the larger context in the society, his narrative was perceived as lacking in credibility after the debate.

Knowing Chu's past record, Tsai's debate tactic focused on pointing out the lack of credibility in his character by drawing the audience/voters' attention to both his attitude change from initial denial to eventual tenacity when it came to joining in the election, and the way he replaced the original presidential candidate by allegedly undemocratic means. In response to her question on his inability to keep his previous promise, and, namely, an attack on his credibility as a politician, either as a present mayor or as a presidential candidate, Chu first acknowledged that he was caught in a dilemma. On the one hand, he recognized his responsibility and the promise he had made to finish his mayoral term, and on the other, he reckoned that had he not chosen to run in rivalry with Tsai, the result would be that "DPP takes power and leads Taiwan into a very horrible state" (line 2-3). Twice he responded with the questions, "what decision should I make?" (line 6) and "what should we do?" (line 8), paving way for his narrative in which he justifies his course of action on the presupposition that Taiwan would be in tribulations if the opposing party DPP won the election. In this way, he implied that judging from the circumstances, running for presidency would be the wise thing to do for the greater good. The narrative is a strategy he employed to vindicate his choice and to restore the "existential coherence" of his political self. In the narrative, he referred to an epiphanic encounter with an Ama that prompted him to make this final decision. It begins with a Labovian orientation of place and situation (Labov and Waletzky 1967), followed by a short passage of constructed dialogue, and ends with his evaluation. Note that the data originally occurred in Mandarin Chinese; material spoken in Taiwanese appears in italics (see Appendix I for full transcript with Pinyin and glosses).

(1) 7. I remember once when I went praying in Tamsui,

8. An Ama told me, "Mayor, you have to run for presidency."

9. I said, "I have promised all citizens of New Taipei City."

10. The Ama said, "If you don't, not even the gods will forgive you."

11. "You have to do this for Taiwan, not for yourself."

12. These words touched me greatly.

By “casting thoughts and speech in dialogue," according to Tannen (2007), the storyteller "creates particular scenes and characters" (p. 107). Instead of directly rejecting the accusation by his debate rival Tsai by explicitly expressing his thoughts, Chu frames the process in which he changes his attitude and makes the final decision in a conversation between him and the Ama, 
transforming a statement into dialogue to create involvement by "establishing and building on a sense of identification" between himself and the audience/voters (Tannen 2007:107). This way, even though Chu's narrative is situated in a context where his credibility is being examined and his "existential coherence" being questioned, the narrative and the dialogue in it are "constructed in service of some immediate interactional goal" (Tannen 2007:108), that is, vindicating his action; direct quotations from the Ama in the narrative involve the audience through participation in sense making and, therefore, diverge their attention from questioning his motive.

Further, Chu establishes the Ama and himself as holding opposite positions by presenting dialogue consisting of three turns, with each turn indicating the progression of his attitude change. At level 1, the Ama is positioned in relation to Chu as someone who imposes upon him the idea that urges him to run for presidency (An Ama told me, "Mayor, you have to run for presidency," line 8). This juxtaposition persists through the constructed dialogue, positioning the Ama specifically as the agent performing the action and holding a certain belief. When it comes to his turn to speak, Chu regains agency in the narrative by displaying his awareness of his promise and his responsibility as the mayor (I said, "I have promised all citizens of New Taipei City," line 9). This is supposed to present him as a person who stands by his earlier duty and promises to serve that duty. When the conversation takes the final turn, Chu once again positions himself relationally as the person being addressed and who passively accepts the Ama's proposition (You have to do this for Taiwan, not for yourself, line 11). The direct quotation, then, serves as "an evaluative device which dramatizes the key elements in narrative" in order for candidates to "indirectly and implicitly invoke and project some positive characteristics of themselves" (Kuo 2001:195). The evaluative clause in line 12 suggests that Chu has agreed to decline his responsibility as a mayor and has accepted the plea to join the election (These words touched me greatly). This way, Chu tactfully answers Tsai's question by providing a narrative that accounts for his decision and tacitly justifies his failure to keep his promise considering that he was committed to the greater good of all people in Taiwan at the Ama's request.

At level 2, Chu employs two strategies, providing detailed imagery and codeswitching, to reinforce for the audience the authenticity of this encounter in the narrative and to rationalize and justify his action. According to Tannen (2007), details in narrative "provide a sense of authenticity, both by testifying that the speaker recalls them and by naming recognizable people, places, and activities," contributing to the speaker's presentation of self (p. 138). In the story's orientation, when Chu sets up the background of the story, he presents himself as a pious person who goes to a temple to pray (I remember once when I went praying in Tamsui, line 7). Praying at a temple is a common practice that politicians in Taiwan do in front of the camera. Here he reinforces that image and paves the way for what is coming up next. He names the location, Tamsui, creating a sense of authenticity by arousing the audience's perception of location credibility. This allows people to associate the place with the activity, especially when Tamsui is known for many temples. The majority of the prayers at the temples are elderly people, making it more convincing that Chu met the Ama when he was there.

Also, starting in line 8, Chu switches from Mandarin Chinese to Taiwanese when telling the story. With over $60 \%$ of the population using it on a daily basis, Taiwanese is associated with a strong sense of national identity as well as a large group of working class and people of older generations because younger generations in Taiwan have less access to Taiwanese. As Lo (1999) argues, "the act of codeswitching itself makes salient the indexical links between a language, categories of ethnic identity, and speech community membership" (p. 462). This juncture of codeswitching in the debate can be seen as a move on Chu's part to address directly the speech 
community of Taiwanese, evoking a sense of familiarity and taking an accepting and supportive stance toward the working class in Taiwan. At the same time, it is part of the authentication. Telling the story with an Ama in Taiwanese calls for corroborative recognition from the audience of the story itself and the storyteller. It again makes the Ama character more real and the politician more believable.

When Chu presents the grandma character and positions himself vis-à-vis the Ama, he alludes to these characteristics associated with Ama at level 3. Here the Ama can be interpreted as a symbol of the working class or middle class citizens. Animating her voice in direct quotes as an external source makes the narrative more persuasive as a rhetorical device. When an Ama tells him to run for office, Chu implies that most people in Taiwan support his decision and it helps the candidate connect to a large part of the audience. Simultaneously, he shows that his decision is for the greater good, once again justifying his motive of running for presidency as opposed to being a city mayor, which would be for his own good ("You have to do this for Taiwan, not for yourself," line 11). Lastly, he references the local religion in Taiwan and the concept of retribution that one will be punished by the gods for not doing the right thing, which consequently prompted him to make "the right decision" (The Ama said, "If you don't, not even the gods will forgive you, line 10). This reference to traditional Taoist religious belief ties back to the location; the event took place at a temple. By telling the story, it is as if the conflict in Chu's political self is resolved when the story reaches its resolution.

Chu's attempt to decline responsibility is evidenced by his positioning in the narrative. However, the traditional Labovian first-person narrative that is meant to enhance authenticity and thus restore Chu's credibility was not corroborated by the public after the debate. For one thing, in the immediate context of the debate, the political aim of Chu's narrative is conspicuously defensive and argumentative as shown in the speech in which the narrative is embedded. The narrative emerges in his speech in response to a question, a context where his credibility as a candidate is put to test. Prior to and subsequent to the narrative, Chu foments the opposition between DPP and KMT, Tsai and himself, to reinforce the image that the political circumstances called for his justifiable action of joining the election. This explains why the narrative, designed as a rhetorical device, is perceived as less convincing because the embedding of Chu's narrative turned out to accentuate his ulterior motive. The technique is in line with what Holly (1989) calls "non-communication," that is, "concealing intentions and conveying meanings at the same time" (p. 123). Chu attempts to authenticate the narrated event that justifies his decision to run for presidency and vindicate his action of breaking his promise and failing to fulfill his responsibility as mayor. Consequently, People turn to view Chu's encounter with the grandma as a feeble attempt to justify his motive, corresponding to Holly's description that "trustworthiness of politicians is connected with the way they take or refuse responsibility for meaning components which are intended and conveyed" (p. 122-123).

“Tamsui Ama” (淡水阿嬤, dànshuǐ āmā), a term that quickly went trending following the day of the debate, was turned into the subject of a wide variety of parodies, ranging from graphic illustrations, song adaption, idiom coinage, to traditional Taiwanese puppet show, exactly because the character portrayal left considerable room for people to play with their imagination. The rapid and pervasive emergence of all sorts of parodies arguably points to the lack of credibility both in his narrative and in his reputation. The public in general finds it impossible to identify the person in Chu's narrative and, therefore, casts doubts on the authenticity of it, thinking that the Ama in Chu's narrative is no more than a fictional character invented to embody the Taiwanese working and middle class. 


\subsection{SOONG'S NARRATIVE}

In the same debate, James Soong, the PFP candidate, provided a narrative that featured another Ama in Taiwan. There are, however, a few major differences between the two narratives, which I address primarily to explain the relatively negative reception of Chu's. First, compared to Soong's story of an Ama, Chu's is situated in a context of justification and defense. Soong's narrative, on the other hand, is embedded in his concluding statements where he provided another narrative about his father in addition to this one. His narrative is thematically coherent in the way that it undergirds his political visions, whereas Chu's narrative comes off as rather abrupt. Soong's narrative operates differently than Chu's as his is not a first-person story; Soong did not know or interact with the Ama character in person and he does not claim to have done so. He showed a photo of the Ama that he had brought with him while telling the narrative as a visual aid to frame the situation and drawing an analogy between him and the Ama character to highlight a sense of persistence. (Original data in Mandarin Chinese. See Appendix II for full transcript with Pinyin and glosses.)

(2) 1. I have a photo with me.

2. I believe Ms. Chu Chen must know this person.

3. This is Zhuan-Chu Yu-nü, wife of a laborer.

4. Every day she sold 10-dollared meals,

5. So that everyone is fed.

6. But I can tell everyone.

7. For 50 years she only took 10 dollars.

8. This tells us,

9. This day in Taiwan, many people still live in hardships.

In telling the narrative, Soong provides a nonverbal "contextualization cue" (Gumperz 1998) to signal a change in reference and participants' activity and to draw attention to the Ama character. This is synonymous with providing details. He not only gives the name of the Ama but also shows a photo of her as evidence (This is Zhuan-Chu Yu-nü, wife of a laborer, line 3), which contributes to his absolute credibility. Contrary to Chu's story, however, Soong's narrative is not about his personal experience; it is also not a traditional Labovian narrative in that it is habitual. Even though he is not in the story as a character, Soong makes a parallel between himself and the Ama. At level 1, the Ama character is portrayed as serving others selflessly over a long period of time (For 50 years she only took 10 dollars, line 7). This helps project the image that Soong is also a public servant by analogously positioning himself next to this Ama. The time span also corresponds to his display of self as a man of persistence, as Soong has run in presidential election four times at that time in 2000, 2004, 2012, and 2016.

At level 2, in addition to showing the photo to the audience, Soong uses eye contact to recruit one audience member, Chu Chen, the mayor of Kaohsiung City and a famous politician of DPP. This move serves several purposes. First, Soong finds himself a witness to corroborate his narrative (I believe Ms. Chu Chen must know this person, line 2), enhancing the credibility of the story character. As Bucholtz and Hall (2005) describe, "the detailing of the chain of narration whereby the teller heard the tale also provides evidence for his right to tell it, thus authenticating both the narrative and his interactional identity as its narrator" (p. 602). Second, Soong creates an alliance with someone from another political party in telling his narrative. This accentuates his 
relatively more neutral and bi-partisan candidacy as the third party, not involved in the longstanding opposition between KMT and DPP in Taiwan's politics. Third, he seems to share the tellership with Chen while knowing that he holds the floor because of the debate format, making his story more credible because of the co-constructed nature. The recruitment of Chen also has to do with her being the mayor of Kaohsiung City, where the majority of its residents are working class and speak Taiwanese. This is again brought up when Soong mentions that the Ama is the wife of a laborer, not only alluding to the characteristics associated with Ama mentioned above but also addressing directly the working class in Taiwan.

Soong then directs the audience's/voters' attention from the past to the future hypothetical, positioning himself as someone who has witnessed the hardships in Taiwan while promising a better future. Also, the pronominal choice is the focus here when Soong uses first-person plural wormen in Mandarin Chinese to refer to and to address people in Taiwan, indicating that we are all in this together and creating a sense of unity and inclusiveness. The extensive use of repetition makes salient the key concepts that Soong wants to convey. (Original data in Mandarin Chinese. Bold font and arrows used to highlight lines of particular analytic interest. See Appendix II for full transcript with Pinyin and glosses.)

(3) 10. Our next generation will not go on living in hardships like this.

11. After I am elected,

12. I will have our Bank of Taiwan make a coin.

13. On it is the photo of this grandma.

$\rightarrow$ 14. To make people in Taiwan remember forever that people in Taiwan are kind,

$\rightarrow$ 15. People in Taiwan traveled the past of poverty.

$\rightarrow$ 16. People in Taiwan cannot allow the next generation to live in hardships anymore.

$\rightarrow$ 17. We have to work harder!

$\rightarrow$ 18. We have to make the freedom and democracy,

$\rightarrow$ 19. We have to keep people in Taiwan alive. $\langle s o b s\rangle$

Tannen (2007) claims that repetition creates coherence in discourse and interpersonal involvement as it "not only ties parts of discourse to other parts, but it bonds participants to the discourse and to each other, linking individual speakers in a conversation and in relationships" (p. 61). At this point, Soong's narration at level 2, or in the interaction, has moved from recounting a story character and her actions to making it relevant to the here and now and to the recipients. With the use of repetition, both lexical and syntactic one (people in Taiwan, line 14-16 and we have to, line 17-19), Soong continues his narration in a rhythmic way that involves the audience/voters by creating closeness and a sense of unity.

At level 3, the repetition even brings together several different discourses, including the kind-heartedness of Taiwanese people (To make people in Taiwan remember forever that people in Taiwan are kind, line 14), the economic hardships in the history of Taiwan (People in Taiwan traveled the past of poverty, line15), his political belief in democracy (We have to make the freedom and democracy, line 18), and the security of people's livelihood (We have to keep people in Taiwan alive, line 19). The conglomeration projects Soong's political visions for the future as a coherent whole. Thus, Soong outlines his political visions and promotes a coherent image of himself by linking the past, present and future with an allusion to the social meaning of Ama. In the previous extract, Soong establishes a connection between himself and the Ama character based on the association of Ama with her labor and her contribution to the economy 
and people's lives. Here, Soong positions the Ama character as a metaphor of resilience in the time of economic hardships. He has witnessed the struggles of Taiwanese people in the past and he is here to run for presidency now with a promise of a better future for the next generation. This is in the same vein as what Shenhav (2005b) terms as "concise narrative," or "segments (a few paragraphs) of a political text (e.g. a speech, an interview, a political discussion) that contain its entire chronological range" (p. 316). This way, Soong positions himself in the narrative as having not only a persistent characteristic but also a coherent persona over time. His narrative helps establish the "existential coherence" of his political self in Duranti's (2006) terms.

Soong's narrative, in contrast to Chu's, received little attention and media coverage, despite the shared focus on an Ama character. While Chu's narrative hit the headlines and became widely satirized on the Internet, Soong's narrative appeared only briefly in the news. The immediate context of the debate in which the narrative is embedded, namely Soong's closing statements, is not as provocative and charged with tension as cross-examination in Chu's example. Instead, the Ama character was regarded lightly as mere factual information to support Soong's claim while the narration was treated as a part of his performance in the debate. Unlike the Ama in Chu's narrative that was deemed by the public to be fictitious, Soong's Ama character was so real (including a photograph) that there was no room for questioning. This corresponds to what Labov (1982) notes as the inverse relationship between reportability and credibility: "the more reportable an event is, the less credible it is" (p. 228). In the social context, while the Ama was used to paint Soong in a positive light, people were also well aware of his past political engagement, so much so that the narrative did not evoke strong reactions from the public. It was recognized as an exemplar of his well-known political identity, and is thus not as "reportable" (Labov and Waletzky 1967) as Soong's.

\section{Conclusion}

Bottici (2010:920) asks, "who tells the relevant stories?" and "which forces determine the crucial narrative plots?" In this paper, I have demonstrated how narrative is employed by two candidates in Taiwan's 2016 presidential debate to present themselves as credible through storytelling and how they make their narratives relevant to the debate context to achieve their political aims. In a sense, both narratives are fundamentally argumentative, as Fairclough and Fairclough (2012) state; they were told to make an argument and to convince the audience of a certain political claim. However, Chu's narrative comes to be perceived as a rhetorical device for vindication because it was told during cross-examination when he was questioned by Tsai for his motive in order for him to justify his decision and deflect the accusation. This is made salient, as we have seen, by how he positions himself in the story by declining his responsibility as the city mayor in a way that puts the onus for this decision on an unnamed Ama who urges him to do so for the good of all of Taiwan. On the other hand, Soong's narrative is seen as an exemplar of his political visions as he analogously positions himself parallel to the Ama against the backdrop of economic hardships. In the analysis, I have shown that narrative in political discourse can be used as a rhetorical device, the intersection of storytelling activity and argumentation. Further, I have illustrated how the two candidates positioned themselves at different levels by alluding to the common associations with Ama to construct a political self that is existentially coherent, from the past to present, and from the local context of the debate to the hypothetical future. Finally, I showed that their narratives were perceived differently because of narrative context. Although neither of them won the election, Chu and Soong drew on narrative as a powerful strategy; for $\mathrm{Chu}$, the narrative was compromised by context, both its immediate context in the 
debate where attack and defense abound, and its larger social context where politicians are evaluated and where events depicted in stories are assessed in light of this. The analysis adds to the emerging research on narratives in political discourse and contributes to a better understanding of how narrative functions within the constraints of its context in Taiwan's political debate discourse.

\section{References}

BAMBERG, Michal. 1997. Positioning Between Structure and Performance. Journal of Narrative and Life History, 7, 335-342.

Benoit, William L. and Wells, William T. 1996. Candidates in conflict: Persuasive attack and defense in the 1992 presidential debates. Tuscaloosa: University of Alabama Press.

BotTICI, CHIARA. 2010. Narrative. In Mark Benvir (ed.) Encyclopedia of political theory. 919920. Thousand Oaks: Sage.

CARRANZA, IsOLDA E. 1999. Winning the battle in private discourse: Rhetorical-logical operations in storytelling. Discourse \& Society, 10(4), 509-541.

DAVIES, BROWYN and HARRÉ, ROM. 1990. Positioning: The discursive production of selves. Journal for the Theory of Social Behaviour, 20(1), p. 44-63.

DE FinA, AnNA. 2013. Positioning level 3: Connecting local identity displays to macro social processes. Narrative Inquiry, 23(1), 40-61.

DURANTI, ALESSANDRO. 2006. Narrating the political self in a campaign for U.S. congress. Language in Society, 35(4), 467-497.

FAirclough, IsABela and FAIRCLOUgh, Norman. 2012. Political discourse analysis: A method for advanced students. London: Routledge.

FAIRCLOUGH, NORMAN L. and WODAK, RUTH. 1997. Critical discourse analysis. In Teun A. van Dijk (ed.), Discourse studies: A multidisciplinary introduction, Vol. 2. Discourse as social interaction. 258-284. London: Sage.

Gamson, William A. 1992. Talking Politics. Cambridge: Cambridge University Press.

GOFFMAN, ERVING. 1974. Frame analysis: An essay on the organization of experience. Cambridge, Mass: Harvard University Press.

GuMPERZ, JoHn J. 1982. Discourse strategies. Cambridge: Cambridge University Press.

HodGES, ADAM. 2011. The "war on terror" narrative: Discourse and intertextuality in the construction and contestation of sociopolitical reality. New York: Oxford University Press.

KuO, SAI-HUA. 2001. Reported speech in Chinese political discourse. Discourse Studies, 3(2), 181-202.

KUO, SAI-HUA. 2002. From solidarity to antagonism: The uses of the second-person singular pronoun in Chinese political discourse. Text, 22(1), 29-55.

LABOV, WILLIAM. 1982. Speech actions and reactions in personal narrative. In Deborah Tannen (ed.) Georgetown University round table on language and linguistics 1981: Analyzing discourse: Text and talk, 219-247. Washington, DC: Georgetown University Press.

LABOV, WILLIAM and WALETZKY, JOSHUA. 1967. Narrative analysis: Oral versions of personal experience. In June Helm (ed.) Essays on the verbal and visual arts, 12-44. Seattle: University of Washington Press.

Linde, CHARLOTTE. 1993. Life stories: The creation of coherence. New York: Oxford University Press. 
LO, ADRIENNE. 1999. Codeswitching, speech community membership, and the construction of ethnic identity. Journal of Sociolinguistics, 3(4), 461-479.

Miller, Hugh T. and Fox, Charles J. 1995. Postmodern Public Administration. Toward Discourse. London, CA: Sage.

OCHS, ELINOR and CAPPS, LISA. 2001. Living narrative. Cambridge, MA: Harvard University Press.

ODDO, JOHN. 2011. War legitimation discourse: Representing 'Us' and 'Them' in four US presidential addresses. Discourse \& Society, 22(3), 287-314.

SCHIFFRIN, DEBORAH. 1996. Narrative as self-portrait: Sociolinguistic constructions of identity. Language in Society, 25(2), 167-203.

SCHUBERT, CHRISTOPH. 2010. Narrative sequences in political discourse: Forms and functions in speeches and hypertext frameworks. In Christian R. Hoffmann (ed.) Narrative revisited: telling a story in the age of new media. 143-162. Amsterdam: John Benjamins Pub. Company.

SCLAFANI, JENNIFER. 2015. Family as a framing resource for political identity construction: Introduction sequences in presidential primary debates. Language in Society, 44(3), 369399.

SHENHAV, SHAul R. 2005a. Thin and thick narrative analysis: On the question of defining and analyzing political narratives. Narrative Inquiry, 15(1), 75-99.

Shenhav, SHAul R. 2005b. Concise narratives: A structural analysis of political discourse. Discourse Studies, 7(3), 315-335.

SOUTO-MANNING, MARIANA. 2014. Critical narrative analysis: The interplay of critical discourse and narrative analyses. International Journal of Qualitative Studies in Education, 27(2), 159-180.

VAN DIJK, TEUN A. 1997. What is political discourse analysis? Belgian Journal of Linguistics, 11(1), 11-52

YANG, PEI-LING. 2013. A Critical Discourse Analysis of Taiwan's national debate on economic ties with China. Taiwan Journal of Linguistics, 11(2), 83-103.

\section{Appendix I: transcript of Chu's narrative}

1. kěshì dāng wǒ zhīdào, rúguǒ mínjìndăng zhí zhèng, but when I know if DPP hold government 'But when I learned that if DPP takes power,'

2. huì bă táiwān dài rù $y \overline{1}$ gè fēicháng kěpà de jìngjiè, will ACC Taiwan bring into one CL very horrible GEN state

'And leads Taiwan into a very horrible state,'

3. rúguǒ cài zhǔxí nín zhí zhèng, if Tsai chair you-HON hold government

'If Chair Tsai you were to be in power,'

4. huì ràng táiwān rén hěn duō rén de gōngzuò, will let Taiwan person very many person GEN job 'Many people in Taiwan would be rendered unable to,'

5. dōu zuò bù hăo, zuò bù măn, all do NEG good do NEG full

'Do their job well and serve their full term.'

6. zhè shíhòu wǒ gāi zuò shénme yang de xuănzé. 
this time I should make what kind GEN choice

'What decision should I make at this time.'

7. jìdé yǒu yīcì dào dànshuǐ qù bàibài de shíhòu,

remember EXI once to Tamsui go pray GEN time

'I remember once when I went praying in Tamsui.'

8. yīgè āmā gēn wǒ shuō, shuō shìzhăng $\mathrm{a}$, nǐ yīdìng yào chūlái xuăn.

one CL Ama to I say say mayor PT you must have.to come.out elect

'An Ama told me, "Mayor, you have to run for presidency.",

9. wǒ shuō, wǒ yǐjīng chéngnuò suǒyǒu de zán xīnběishì de shìmín.

I say I already promise all GEN we New.Taipei.City GEN citizen

'I said, "I have promised all citizens of New Taipei City.",

10. Āmā gēn wǒ shuō, nǐ rúguǒ bù chūlái, lián tiāngōngbó dōu bù huì yuánliàng nǐ. Ama to I say you if NEG come.out even gods all NEG will forgive you 'The Ama said, "If you don't, not even the gods will forgive you.",

11. nì yào wèi táiwān, bù néng wèi gèrén.

you have.to for Taiwan NEG can for individual

"'You have to do this for Taiwan, not for yourself.",

12. zhè duàn huà ràng wǒ fềicháng de găndòng.

this CL word let I very $\mathrm{C}$ touch

'These words touched me greatly.'

13. wǒ zhīdào, dāng táiwān pèng dào guānjiàn de shíkè,

I know when Taiwan hit PREP critical GEN moment

'I know that when Taiwan is at a critical moment,'

14. dāng mínjìndăng, dāng cài zhǔxí hěn kěnéng bă táiwān dài rù yīgè when DPP when Tsai chair very possible ACC Taiwan bring into one CL

'When DPP and Chair Tsai are likely to take Taiwan into an (.)

15. wúfã fùyuán de shēnyuān de shíhòu, No.way reverse GEN abyss GEN time

'Irreparable abyss,'

16. dāng nǐ měitiān yòng

when you every.day use

'When you have'

17. bù quèdìng, bù āndìng, bù wěndìng de zhèngcè de shíhòu, NEG certain NEG stable NEG consistent GEN policy GEN time

'Uncertain, unstable, inconsistent policies every day,'

18. wǒmen gāi zěnme bàn?

we should how do

'What should we do?'

\section{Appendix II: transcript of Soong's narrative}

1. wǒ shēn shàng dài le yīgè zhàopiàn, I body up carry PT one CL photo 'I have a photo with me.'

2. zhè wèi wǒ xiāngxìn chén jú nüshì yīdìng huì rènshi this CL I believe Chen Chu lady must will know 'I believe Ms. Chen Chu must know this person.' 
3. jiù shì zhuāng zhūyù nŭ, láogōng de qīzi, this BE Zhuan-Chu Yu-nü laborer GEN wife 'This is Zhuan-Chu Yu-nü, wife of a laborer.'

4. měitiān zài mài shí yuán de zìzhùcān, ràng dàjiā chī dé băo, every.day HAB sell ten dollar GEN meal let everyone eat $\mathrm{C}$ full 'Every day she sold 10-dollared meals, so that everyone is fed.'

5. dànshì wǒ kěyǐ gēn zhūwèi shuō, tā màile wǔshí nián zhǐ shōu shí kuài qián. but I can to everyone say she sell-PERF fifty year only take ten CL dollar 'But I can tell everyone; for 50 years she only took 10 dollars.'

6. Zhè jiù shuōmíng,

This just explain

'This tells us,'

7. jīntiān táiwān hái yǒu hěn duō rén hěn jiānkǔ, today Taiwan still EXI very many person very difficult 'This day in Taiwan, many people still live in hardships.'

8. wǒmen xià yī shídài bù yào zài zhèyàng kŭ xiàqù. we next one generation NEG will again this.way difficult RES

'Our next generation will not go on living in hardships like this.'

9. Wǒ dāngxuăn zhīhòu, I elect after 'After I am elected,'

10. wǒ huì qǔng wǒmen táiwān yínháng zuò yīgè tóng bì, I will have we Taiwan bank make one CL copper coin 'I will have our Bank of Taiwan make a coin.'

11. shàngmiàn jiù shì zhège āmā de zhàopiàn. up.side just BE this CL Ama GEN photo on it is the photo of this grandma.

12. Ràng táiwān rén yǒngyuăn jìdé, táiwān rén shì shànliáng de, let Taiwan person forever remember Taiwan person BE kindness PT To make people in Taiwan remember forever that people in Taiwan are kind,

13. táiwān rén shì zǒuguò pínqióng de guòqù de, Taiwan person BE walk-PERF poverty GEN past PT People in Taiwan traveled the past of poverty.

14. táiwān rén bù néng ràng xià yî dài zài zài zhè biān kŭ xiàqù, Taiwan person NEG can let next one generation again at this side difficult RES People in Taiwan cannot allow the next generation to live in hardships anymore.

15. wǒmen yào jiāyóu $\mathrm{a}$ ! we have.to work.hard PT

'We have to work harder!'

16. Wǒmen yào ràng zìyóu mínzhǔ de zhìdù, we have.to let freedom democracy GEN system 'We have to make the freedom and democracy,'

17. wǒmen yào ràng táiwān rén nénggòu huó dé xiàqù, we have.to let Taiwan person can live C RES

'We have to keep people in Taiwan alive.' 